\title{
Influencing Factors on Ground Heat Balance of GSHP System
}

\author{
Xiaohong Zhang ${ }^{1, a^{*}}$, Zehua Liü ${ }^{2, b}$, Chao Zhang ${ }^{3, c}$ and Long Ma ${ }^{4, d}$
}

${ }^{1}$ School of Urban Construction, University of South China, Hengyang, Hunan, 421000, China

a526207973@qq.com, bIzh_usc@163.com, c18790207503@163.com, d1003519468@qq.com

Keywords: ground source heat pump (GSHP); U-tube ground heat exchanger; soil temperature; influence factors

Abstract. Taking an office building in Changsha city, Hunan Province as the research object, its all-year hourly dynamic load is simulated by EnergyPlus software. On this basis, a simulation model of U-tube ground heat exchangers is built with the GSHP design software of GLD2012. The heat balance problem of the ground source heat pump (GHSP) system in long-term operation is discussed from influencing factors of soil thermophysical parameters and backfill materials' thermal conductivity. The simulation results are analyzed to show the reference to the optimal design of the U-tube ground heat exchanger system in engineering practice.

\section{Introduction}

In recent years, there are a crisis of energy shortage and environmental degradation around the world, the GHSP system as an energy saving, environmental protection and renewable energy technology has received attention both at home and abroad for the development and application. However, the GSHP system in the aspect of design, construction and operation still exist some problems. The matching problem of building load and ground heat exchanger in design process, and soil temperature changes caused by unbalanced heat and cold in running process became two great focuses in the application of ground source heat pump system [1].

In hot summer and cold winter zone of China, the building cooling load was often greater than the heat load. If all the building load was borne by the GHSP system, it would cause that the heat exhaust of the system to the soil was more than the heat supply from the soil. Then the soil temperature around U-tube heat exchanger would rise year by year and the heat pump cop would decline gradually [2]. Aimed at the problem mainly, research on influence of the soil temperature variation around U-tube ground heat exchanger offered the reference to alleviate the rise of the soil temperature caused by the imbalance between the heat absorption and release.

\section{Building model and energy consumption simulation}

\section{Building model analysis}

The physical model of research is based on an office building located in Changsha including total construction area of $2844 \mathrm{~m}^{2}$, air conditioning covers an area of $2258 \mathrm{~m}^{2}$, total of 4 layers and total building height of $16.4 \mathrm{~m}$. The architecture model is built up with the help of software Sketchup, as shown in Fig. 1.

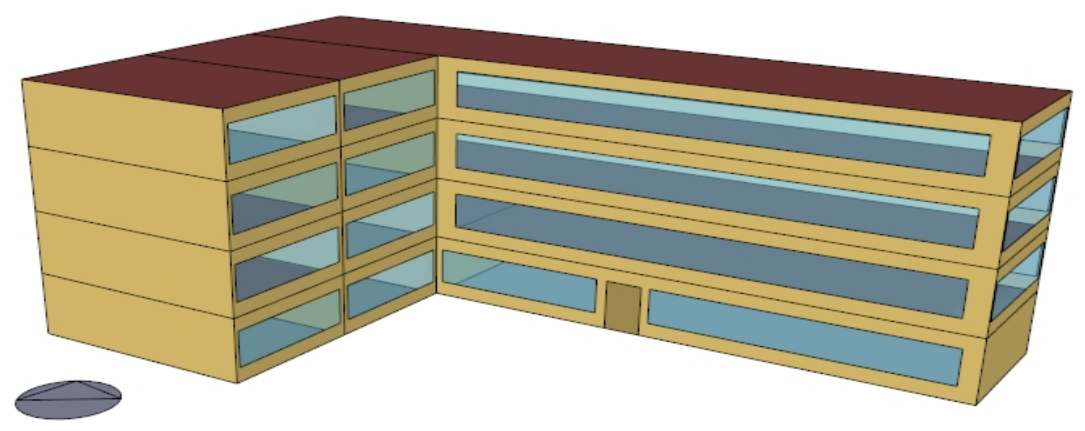

Fig. 1 The building model 
The construction all-year hourly load by the energy consumption simulation is simulated by software EnergyPlus considering meteorological parameters with the Changsha area hourly meteorological data of typical meteorological year in this paper. The building's office hours are 08:00-18:00, summer set temperature of air conditioning room is $26^{\circ} \mathrm{C}$ and relative humidity is $55 \%$, winter set temperature of air conditioning room is $20^{\circ} \mathrm{C}$ and relative humidity is $45 \%$. The main components and thermal parameters of the building envelope are shown in Table 1. Air-conditioning room internal heat gain parameters are shown in Table 2 [3]. Hourly room personnel and the hourly usage of construction equipment and lighting in working days are shown in Fig. 2 [4].

Table 1 The main components and thermal parameters of the building envelope

\begin{tabular}{|c|c|c|}
\hline $\begin{array}{l}\text { Building } \\
\text { envelope }\end{array}$ & Main components & $\begin{array}{l}\text { Heat transfer } \\
\text { coefficient } \\
{\left[\mathrm{W} /\left(\mathrm{m}^{2} \cdot \mathrm{K}\right)\right]}\end{array}$ \\
\hline Roof & $\begin{array}{c}\text { Concrete slab }(40 \mathrm{~mm})+\text { Cement mortar }(20 \mathrm{~mm})+\text { Fine aggregate } \\
\text { concrete }(40 \mathrm{~mm})+\text { Polystyrene board }(100 \mathrm{~mm})+\text { Waterproof layer }(6 \mathrm{~mm})+\text { Cement } \\
\text { mortar }(20 \mathrm{~mm})+\text { Reinforced concrete }(120 \mathrm{~mm})+\text { Mixed mortar }(20 \mathrm{~mm})\end{array}$ & 0.363 \\
\hline $\begin{array}{l}\text { Exterior } \\
\text { wall }\end{array}$ & $\begin{array}{l}\text { Mixed mortar }(20 \mathrm{~mm})+\text { Insulation board }(50 \mathrm{~mm})+\text { Aerated } \\
\text { concrete }(20 \mathrm{~mm})+\text { Cement mortar }(20 \mathrm{~mm})\end{array}$ & 0.571 \\
\hline $\begin{array}{c}\text { Interior } \\
\text { wall }\end{array}$ & Mixed mortar(20mm)+Aerated concrete $(200 \mathrm{~mm})+$ Cement mortar $(20 \mathrm{~mm})$ & 0.899 \\
\hline Floor & $\begin{array}{l}\text { Cement mortar }(20 \mathrm{~mm})+\text { Fine aggregate concrete }(50 \mathrm{~mm})+\text { Concrete } \\
\text { block }(300 \mathrm{~mm})+\text { Fine aggregate concrete }(50 \mathrm{~mm})+\text { Waterproof } \\
\text { layer }(6 \mathrm{~mm})+\text { Mixed mortar }(20 \mathrm{~mm})+\text { Fine aggregate concrete }(100 \mathrm{~mm})\end{array}$ & 1.843 \\
\hline $\begin{array}{l}\text { External } \\
\text { windows }\end{array}$ & Hollow glass $(6+12 A+6) \mathrm{mm}$ & 2.3 \\
\hline
\end{tabular}

Table 2 Internal heat gain parameters of air-conditioning room

\begin{tabular}{cccc}
\hline Room type & $\begin{array}{c}\text { The per capita area of indicators } \\
{\left[\mathrm{m}^{2} / \text { person }\right]}\end{array}$ & $\begin{array}{c}\text { Lighting power density } \\
{\left[\mathrm{W} / \mathrm{m}^{2}\right]}\end{array}$ & $\begin{array}{c}\text { Device power density } \\
{\left[\mathrm{W} / \mathrm{m}^{2}\right]}\end{array}$ \\
\hline Office & 8 & 11 & 13 \\
Meeting room & 2.5 & 11 & 5 \\
Corridor & 50 & 5 & 0 \\
Other & 20 & 11 & 5 \\
\hline
\end{tabular}

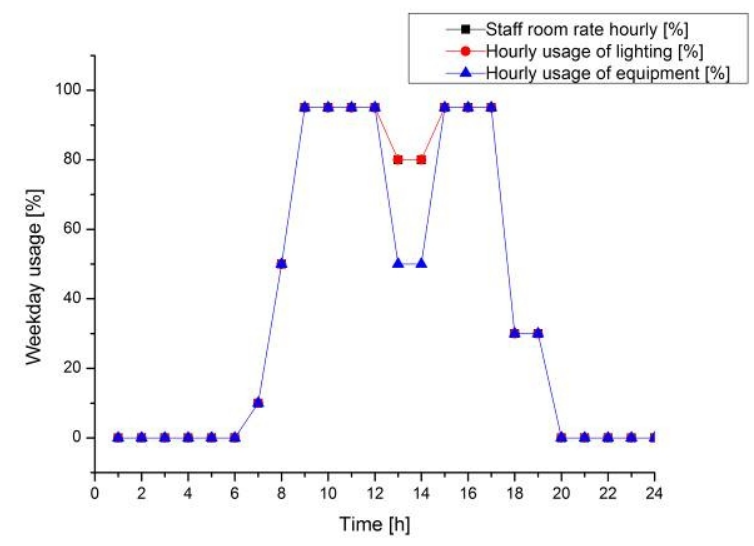

Fig. 2 The hourly usage of office working days



Fig. 3 The year-round outdoor environment dry bulb temperature of Changsha

\section{The simulation results of all-year hourly load}

The year-round outdoor environment dry bulb temperature of Changsha is shown in Fig. 3. The simulation results of the hourly calculation of annual cooling and heating load by the software EnergyPlus are shown in Fig. 4. However, in the actual operation process of air conditioning system, it won't appear the conditions as shown in Fig. 4 that running the system to meet small cooling and heating load in the transition seasons. So according to the actual engineering case, the simulation results are corrected as shown in Fig. 5. 
As shown in Fig. 3, the load characteristics of the building was determined by the office building of the climate characteristic of hot summer and cold winter zone. Combined with Fig. 5, the building load changes over the outdoor dry bulb temperature. The building need refrigeration in summer and heating in winter, and the building load have cold load characteristics of the dominant. The biggest cooling load for the whole year is $280.8 \mathrm{~kW}$, and the biggest heat load is $148.2 \mathrm{~kW}$. Because of the building cooling load in summer greater than the heat load in winter, the heat released to the soil in summer through the ground heat exchanger is greater than extracted from the soil in winter. Then the soil temperature around the U-tube ground heat exchanger would rise gradually. And after the GSHP system running for a long time, the operation effect is much affected by soil temperature field around the U-tube ground heat exchanger. The following would explore the influence factors of temperature field around the U-tube ground heat exchanger and its influence law.



Fig. 4 The simulation results of all-year hourly cooling and heating load of the building

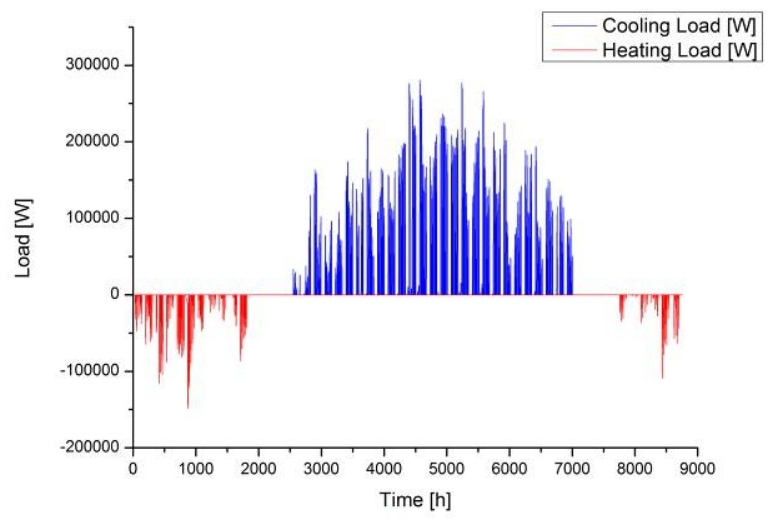

Fig. 5 The modified results of all-year hourly cooling and heating load of the building

\section{The influence factors analysis of soil temperature around the U-tube}

The GSHP systems transfer heat to the ground or regard the ground as the heat exchanger, which is influenced by two key factor of the structure of the U-tube ground heat exchanger and heat transfer performance of the ground. In the heat transfer of engineering application, usually bounded by borehole wall, the involved space region is divided into the rock-soil portion outside the drill hole and U-tube portion inside the drill hole. The heat transfer resistance outside the drill hole comprises two parts. One is rock-soil layer thermal resistance from drill hole wall to undisturbed distal medium which depends on thermal conductivity of the rock soil and the working time of thermal load. And the other is a kind of attached heat resistance formed by the interference of temperature field around the U-tubes. The heat transfer resistance inside the drill hole is primarily made up of the resistance of tubal material and backfill material outside the tubes [5]. Based on the above analysis, the soil temperature variation around U-tube problem of GSHP system in long-term operation is discussed from such factors as soil thermophysical parameters and thermal conductivity of backfill materials.

Based on the simulation results of the hourly calculation of annual cooling and heating load, a simulation model of U-tube ground heat exchangers is built up by the GSHP design software GLD2012. To choose parameters of heat pump units are as follows: Rated conditions refrigerating capacity $\mathrm{Q}=280.8 \mathrm{~kW}$, refrigerating power input $\mathrm{W}=43.51 \mathrm{~kW}$, Rated conditions heating capacity $\mathrm{Q}=268.8 \mathrm{~kW}$ and heating power input $\mathrm{W}=75.12 \mathrm{~kW}$. The circulating water flow of ground heat exchanger system is $929.69 \mathrm{~L} / \mathrm{min}$. The inlet water temperature of heat pump units is set as $30{ }^{\circ} \mathrm{C}$ in summer and is set as $10{ }^{\circ} \mathrm{C}$ in winter. Vertical single U-tube ground heat exchanger is chosen and the placement form of two pipe in borehole is average spacing.

\section{Effect of soil thermophysical parameters to soil temperature around U-tube}

The soil thermophysical parameters mainly includes two parameters, one is soil thermal conductivity $(\lambda)$, the other one is thermal diffusivity (a). The coefficient of thermal conductivity of soil is indicated by the heat transfer ability of the earth, it depends on the composition of solid material in the soil, the 
relative content of water and air[6]. Thermal diffusivity is a measure of land transfer and store heat capacity, it depends on the soil components, dry density and moisture content of soil. Its definition is $a=\lambda / \rho c$. Under the following six kinds of typical soil and rock are studied and their thermophysical parameters are shown in Table 3.

Table 3 The thermophysical parameters of typical soil and rock

\begin{tabular}{cccc}
\hline Soil type & $\begin{array}{c}\text { Soil thermal conductivity }(\lambda) \\
{[\mathrm{W} /(\mathrm{m} \cdot \mathrm{K})]}\end{array}$ & $\begin{array}{c}\text { Thermal diffusivity (a) } \\
10^{-6}\left[\mathrm{~m}^{2} / \mathrm{s}\right]\end{array}$ & $\begin{array}{c}\text { Density }(\rho) \\
{\left[\mathrm{kg} / \mathrm{m}^{3}\right]}\end{array}$ \\
\hline Dense clay & 1.2 & 0.63 & 1925 \\
Light clay & 0.8 & 0.59 & 1285 \\
Dense sand & 2.2 & 1.62 & 1925 \\
Light sand & 1.6 & 0.82 & 1925 \\
Limestone & 2.4 & 0.97 & 2650 \\
Limestone & 3.8 & 1.51 & 2650 \\
\hline
\end{tabular}

In the modelling, the drilling depth was the value of $80 \mathrm{~m}$, the number of drilling was setting as 40 , borehole spacingwas $4 \mathrm{~m}$ and backfill materials' thermal conductivity was $1.5 \mathrm{~W} /(\mathrm{m} \cdot \mathrm{K})$. Aimed at six kinds of soil and rock respectively, the result of different types of soil thermophysical parameters on the influence law of soil temperature variation around U-tube would be shown in Fig. 6 when the simulation run time of GSHP systems could be 1, 5, 10, 15 and 20 years.

As shown in Fig. 6, when the setting parameters keep constant, if the running time of system was short, the soil thermophysical parameters on the effect of soil temperature field around the U-tube was not significant. But as the growth of the running time, the influence was gradually obvious. When the higher the soil thermal conductivity, the better the performance of heat transfer of soil, the less the temperature rise caused by system for a long time running. After the system was ran 20 years, the temperature rise of soil was $2.7^{\circ} \mathrm{C}$ when the soil around the U-tube was dense sand, which the thermal conductivity was $2.2 \mathrm{~W} /(\mathrm{m} \cdot \mathrm{K})$. But for the thermal conductivity was $2.4 \mathrm{~W} /(\mathrm{m} \cdot \mathrm{K})$ of limestone, the temperature rise was $2.4{ }^{\circ} \mathrm{C}$. Therefore, for the soil thermal conductivity was similar, the temperature rise of soil around U-tube was the lowest when the soil was limestone.

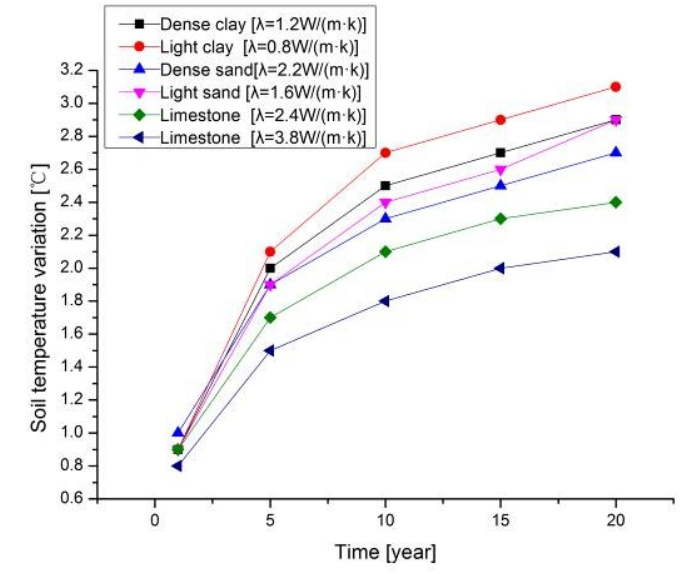

Fig. 6 Effect of soil thermophysical parameters to soil temperature around U-tube

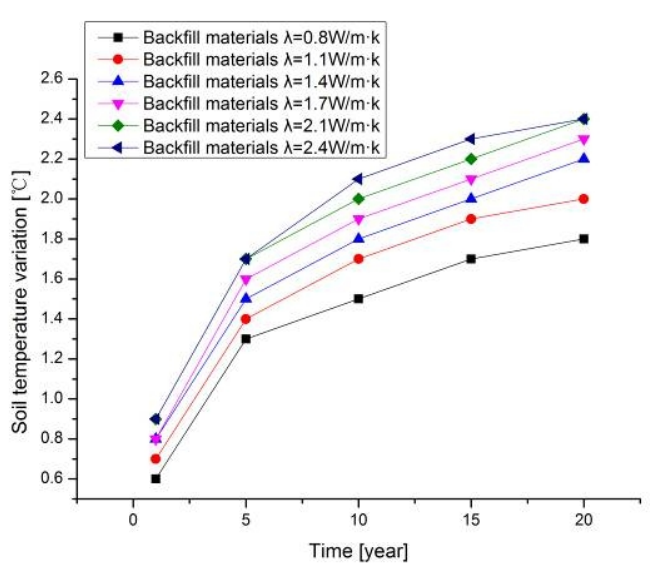

Fig. 7 Effect of backfill materials' thermal conductivity to soil temperature around U-tube

\section{Effect of backfill materials' thermal conductivity to soil temperature around U-tube}

Backfill is a important link in construction process of U-tube ground heat exchanger, it is to point to in after drilling and the completion of the U-tube, to inject drilling backfill material. It between buried pipe and borehole wall, which is used to enhance the heat transfer of buried pipe and the surrounding rock and soil. At the same time, it can prevent surface water by boring to permeate underground and prevent cross contamination between different aquifers. Generally, the scope of thermal conductivity of backfill materials is $0.65 \sim 2.34 \mathrm{~W} /(\mathrm{m} \cdot \mathrm{K})$ [5].

In the modelling, the drilling depth was the value of $80 \mathrm{~m}$, the number of drilling was setting as 40 , borehole spacing was $4 \mathrm{~m}$ and soil thermal conductivity was $2.43 \mathrm{~W} /(\mathrm{m} \cdot \mathrm{K})$. When thermal conductivity of backfill materials were taken for $0.8,1.1,1.4,1.7,2.1$ and $2.4 \mathrm{~W} /(\mathrm{m} \cdot \mathrm{K})$, GSHP 
system simulations was carried out to achieve the influence of different borehole spacing to soil temperature variation around U-tube with the running time of 1, 5, 10, 15 and 20 years.

As shown in Fig. 7, the thermal conductivity of backfill materials on the effect of soil temperature field around the U-tubes was not significant. When the thermal conductivity of backfill materials was less than $1.4 \mathrm{~W} /(\mathrm{m} \cdot \mathrm{K})$, the temperature rise of soil around U-tube was increasing with the growth of the drilling depth. The thermal conductivity of backfill materials was increased, which was good for heat transfer between buried tube fluid and soil. But the heat still was accumulated in the soil around the U-tube. However, when thermal conductivity of backfill materials was increased from 2.1 $\mathrm{W} /(\mathrm{m} \cdot \mathrm{K})$ to $2.4 \mathrm{~W} /(\mathrm{m} \cdot \mathrm{K})$, the temperature rise of soil around the the U-tubes almost unchanged. Therefore, the value of $1.4 \sim 2.1 \mathrm{~W} /(\mathrm{m} \cdot \mathrm{K})$ was for thermal conductivity of backfill materials.

\section{Conclusions}

All-year hourly load modelling was performed by using Energyplus simulation software to establish one office building model in Changsha, Hunan region. And the simulation results were revised on basis of the actual condition of building in paper. Therefore, professional software GLD2012 of ground source heat pump was used to design and calculate ground heat exchanger and the influence of various factors to the soil temperature field around ground heat exchanger was analyzed after the source heat pump system running for a long time. The conclusions were as follows.

The soil temperature around U-tube ground heat exchanger was directly proportional to running time when the system was running 1, 5, 10 and 20 years. As the growth of the running time, the influence of various factors to the soil temperature field around U-tube ground heat exchanger was gradually obvious. The increase of soil thermal conductivity and backfill materials' thermal conductivity was contribute to alleviate soil temperature rise caused by unbalanced heat and cold. The temperature rise of soil around U-tube was decreased with the increase of soil thermal conductivity. Simulation results show that the value of $1.4 \sim 2.1 \mathrm{~W} /(\mathrm{m} \cdot \mathrm{K})$ was appropriate for thermal conductivity of backfill materials considering the investment cost and local geological conditions.

\section{Acknowledgements}

This work was financially supported by the National Natural Foundation (11275093) and the Science and Technology Major Program of Hunan Province (2012GK2026).

\section{References}

[1] Zhu Sheng, Zheng Kailin. Serviceability Analysis of ground source heat pump systems based on Building Energy Simulation [J]. Heating Ventilating \& Air Conditioning, 2013, S1:227-230.

[2] Zhuang Yunchao, Fu Zhengrong, Wang Hanqing. Technic-economic analysis of series connected hybrid ground source heat pump systems [J]. Heating Ventilating \& Air Conditioning, 2012, 05: 68-72.

[3] GB 50189-2005. Design standard for energy efficiency of public buildings. Beijing: China Architecture \& Building Press, 2005.

[4] Lu Yaoqing. Practical Heating \& Air-Conditioning Design Manual [M]. Beijing: China Architecture \& Building Press, 1993: 39240.

[5] Diao Nairen, Fang Zhaohong.Ground-Coupled Heat Pump Technology [M]. Beijing: Higher Education Press, 2006: 118-125.

[6] Ma Wenjuan. Research on design and operation strategies optimization of the hybrid ground source heat pump system with cooling tower [D]. Xi'an University of Architecture and Technology, 2013. 